\title{
ANALISIS PENGARUH INTERFERENSI FREKUENSI TERHADAP KINERJA ACCESS POINT DENGAN TEKNOLOGI IEEE 802.11N
}

\author{
(Analysis of the Effect of Frequency Interference on the Performance of Access point \\ with IEEE 802.11 N Technology)
}

\author{
Suri Darmiantini, I Wayan Agus Arimbawa, Andy Hidayat Jatmika* \\ Dept Informatics Engineering, Mataram University \\ JI. Majapahit 62, Mataram, Lombok NTB, INDONESIA \\ Email: suridarmiantini02@gmail.com, [arimbawa, andy]@unram.ac.id
}

\begin{abstract}
Using the same frequency band in the same coverage area can cause interference. Interference can also be caused by the use of two pieces of the same communication system, or different in the same coverage area. In the same 2 channel interference there is a decrease in bandwidth value of $89 \%$, an increase in jitter value of $97 \%$ and an increase in packet loss value of $21.7 \%$, the same 3 channel interference has a bandwidth reduction of $96 \%$, an increase in jitter value of $99 \%$, and increased packet value loss of $45.7 \%$. Access points with Bluetooth devices around them have decreased bandwidth by $59 \%$, increase in jitter value by $71 \%$, and decrease in packet loss value by $8.34 \%$. On channel 1 and 2 interference, bandwidth decreases by 56\%, increase in jitter value by 59\%, and packet loss increase by $7.6 \%$, interference channel 1 and 3 have a bandwidth decrease of $50 \%$, increase jitter by $47 \%$, and increase packet value loss of 5.54\%. And for channel 1 and 4 interference there is a decrease in bandwidth by $23 \%$, an increase in jitter by $39 \%$, and an increase in the value of packet loss of $4.21 \%$.
\end{abstract}

Keywords: Interference, Wireless, Channel, Bandwidth, Jitter, Packet Loss

*Penulis Korespondensi

\section{Pendahuluan}

Jaringan wireless merupakan salah satu bentuk perkembagan teknologi dalam bidang telekomunikasi. Beberapa teknologi yang mendukung jaringan wireless antara lain adalah WLAN (Wireless Local Area Network) dan WPAN (Wireless Personal Area Network). Salah satu produk WLAN yang paling banyak digunakan saat ini adalah IEEE 802.11n sedangkan pada WPAN aplikasi teknologi yang banyak digunakan adalah Bluetooth. Penggunakan pita frekuensi yang sama dalam suatu daerah cakupan yang sama dapat menyebabkan terjadi interferensi. Interferensi yang terjadi dapat disebabkan karena penggunaan 2 buah sistem komunikasi yang sama, maupun yang berbeda dalam suatu wilayah cakupan yang sama. Penyebab lain terjadinya interferensi pada jaringan wireless adalah tidak terkendalinya radius suatu hotspot. Jika channel yang digunakan antara suatu wireless dengan wireless yang lain bersinggungan maka akan terjadi interferensi yang menyebabkan sinyal wireless kurang maksimal dan menyebabkan performa jaringan menurun.

Untuk mengetahui seberapa besar pengaruh interferensi terhadap penurunan kualitas sebuah sistem komunikasi, maka pada penelitian ini dilakukan pengukuran dan analisis pengaruh interferensi terhadap parameter Quality Of Service (QoS) pada sistem komunikasi wireless dengan standar jaringan WLAN IEEE 802.11n.

Pada penelitian ini akan dilakukan skenario uji coba pada lingkungan tanpa interferensi, lingkungan dengan interferensi jaringan Bluetooth, lingkungan dengan interferensi dari sistem dengan channel yang sama, dan lingkungan dengan interferensi dari sistem dengan channel yang berbeda. Parameter yang digunakan untuk mengukur kinerja jaringan wireless adalah bandwidth, jitter,dan packet loss.

\section{Tinjauan Pustaka}

Pada penelitian [6] bertujuan mengidentifikasi interferensi pada jaringan wireless, dengan menggunakan access point sebagai media dalam wireless. Pada wireless AP yang digunakan secara bersamaan yang diletakkan didaerah yang sama dengan jarak yang berbeda antar kedua access point dan software yang digunakan adalah network stumbler dan wirelessmon. Berdasarkan dari hasil pengujian yang dilakukan, secara umum signal yang 
dihasilkan pada setiap percobaan kurang baik akibat terkena interferensi

Pada penelitian [4] melakukan pengukuran penggunaan frekuensi yang sama menyebabkan penurunan performansi hasil pengukuran menunjukkan sistem Wi-Fi mulai mengalami penurunan throughput sebesar 2,348 Mbps pada jarak 21 meter dari access point. sedangkan sistem Bluetooth mengalami penurunan throughput sebesar 47,914 Kbps pada jarak 1 meter dari acces point dan jarak antar Bluetooth-nya $50 \mathrm{~cm}$.

Pada penelitian [7] telah dilakukan pengukuran dan analisa pengaruhn interferensi terhadap QoS pada standar WLAN IEEE 802.11b. Parameter QoS yang diukur pada penelitian ini adalah jitter, packet loss dan throughput. Hasil pengukuran dan analisa menunjukkan bahwa interferensi dapat mengakibatkan naiknya nilai jitter dan packet loss serta turunnya nilai throughput.

Pada penelitian [8] dilakukan pengukuran pengaruh interferensi antar perangkat WLAN dan pengaruh luas cakupan hotspot terhadap kinerja sistem WLAN 802.11b. hasil penelitian menunjukkan bahwa interferensi berpengaruh menurunan performa pada delay, throughput dan luas cakupan.

\section{Metode Peneltian}

\subsection{Diagram Alir Penelitian}

Mengacu pada permasalahan yang diuraikan pada latar belakang, maka dilakukan analisa pengaruh interferensi frekuensi terhadap kinerja access point dengan teknologi IEEE 802.11n skala lab (testbed). Pada metode penelitian ini akan dijelaskan dengan lebih spesifik mengenai rancangan, tools yang digunakan dan pengujian berdasarkan kondisi tanpa dan dengan interferensi. Adapun diagram alir penelitian secara umum, ditunjukan pada Gambar 1 yang diawali dari studi literatur, lalu mempersiapkan kebutuhan perangkat keras dan perangkat lunak, mempersiapkan scenario pengujian, kemudian dilakukan pengujian terhadap penelitian ini, jika pengukuran sesuai maka dilanjutkan membuat laporan penelitian, jika tidak sesuai dengan yang diharapkan maka akan dikaji ulang skenario pengujian yang dilakukan sampai pengujian tersebut sesuai dengan apa yang diharapkan. Penjelasan detail mengenai diagram alir akan dijelaskan pada Sub Bab selanjutnya.

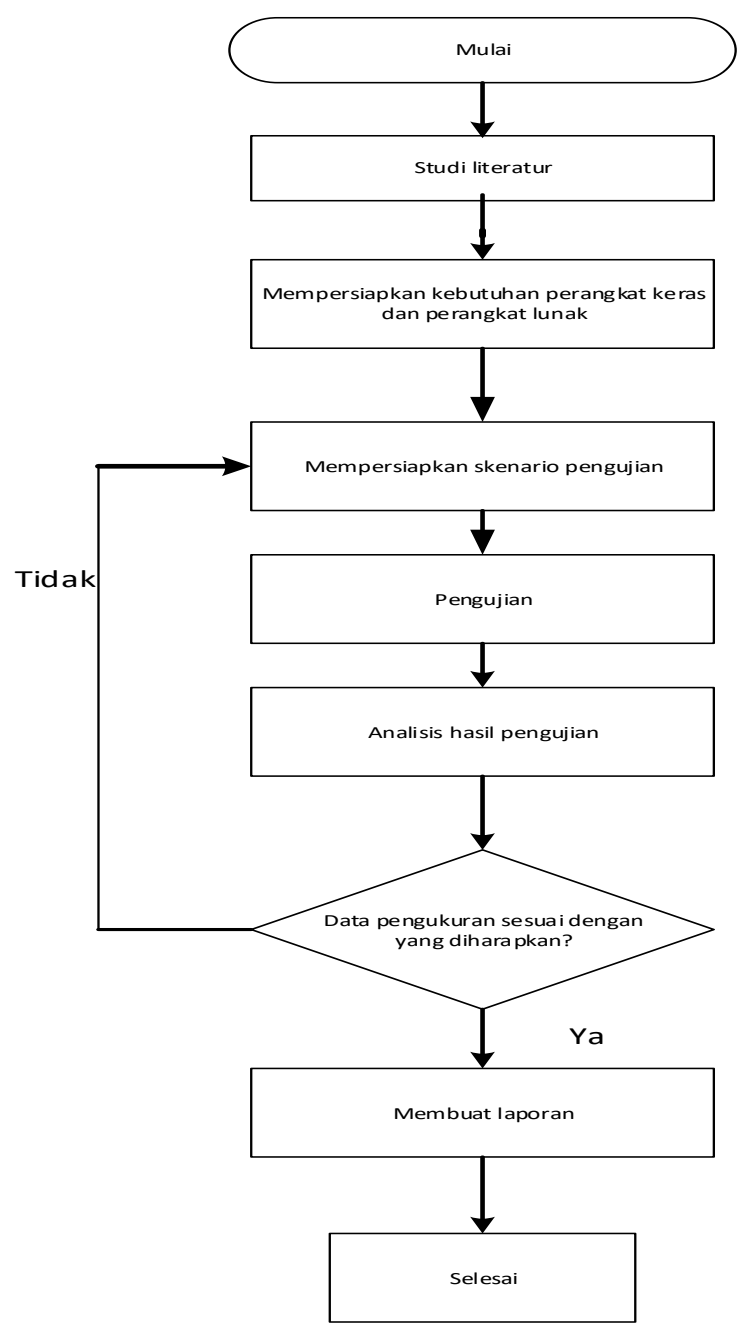

Gambar 1. Diagram alir penelitian

\subsection{Studi Literatur}

Pada studi literatur, dimulai dengan mempelajari konsep serta teori pendukung dan segala sesuatu yang berkaitan dengan yang akan diteliti dalam hal ini interferensi frekuensi terhadap kinerja AP dengan teknologi IEEE 802.11n yang didapatkan dari perpustakaan dan internet baik berupa buku maupuan jurnal ilmiah.

\subsection{Peralatan Penelitian}

Perangkat keras yang digunakan dalam penelitian ini terdiri dari access point, Personel computer (PC)/laptop, abel UTP. Perangkat lunak yang digunakan dalam penelitian ini adalah Jperf dan Inssider.

\subsection{Skenario Pengujian}

Pada penelitian ini akan membahas tentang skenario pengujian, dan parameter yang akan di uji. Pada penelitian ini akan dirancang dua bentuk skenario. Pengukuran dilakukan pada kondisi 
lingkungan tanpa interferensi dan dengan interferensi.

\subsubsection{Pengukuran pada kondisi lingkungan tanpa interferensi.}

Pada skenario ini digunakan dua buah Laptopdan satu buah AP, dimana Laptop pertama sebagai server terhubung dengan AP melalui media kabel, dan laptop kedua sebagai client yang terhubung dengan AP melalui media wireless. Untuk kondisi tanpa interferensi penempatan posisi AP dan Laptop konstan yaitu dengan jarak 5 meter. Skenario pengukuran untuk kondisi tanpa interferensi dilihat pada Gambar 2.

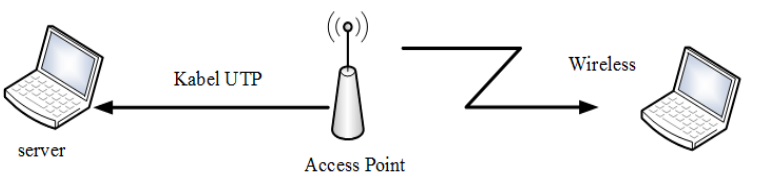

Gambar 2. Skenario pengukuran pada lingkungan tanpa interferensi.

\subsubsection{Pengukuran pada kondisi lingkungan dengan interferensi jaringan Bluetooth.}

Pada skenario ini digunakan dua buah Laptop, satu buah AP dan satu buah keyboard yang memiliki fitur Bluetooth, dimana laptop pertama bertindak sebagai server yang terhubung dengan APmelalui media kabel UTP, laptop kedua sebagai client yang terhubung dengan AP menggunakan wireless, dimana Laptop yang bertindak sebagai client menggunakan keyboard yang memiliki fitur Bluetooth yang digunakan sebagai interfreter (penginterferensi) yang digunakan untuk menginterferensi jaringan. Mekanisme pengukuran yang dilakukan dapat dilihat pada Gambar 3.

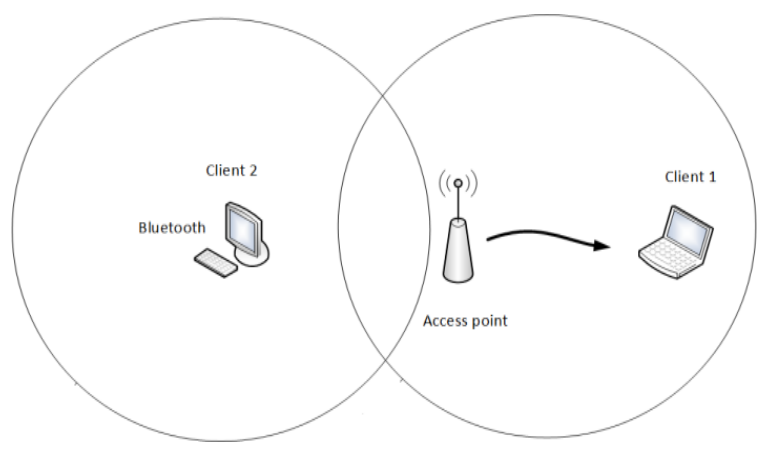

Gambar 3. skenario pengukuran pada lingkungan dengan interferensi jaringan Bluetooth.
4.1.3 Pengukuran pada lingkungan dengan interferensi menggunakan channel interferensi yang sama dan berdekatan.

Pada skenario pengukuran pada lingkungan dengan interferensi menggunaan kanal yang sama dan berdekatan ini dilakukan 4 buah percobaan.

\subsubsection{Pengukuran pada lingkungan dengan interferensi menggunakan dua channel yang sama. \\ Pada skenario ini digunakan 4 buah Laptop dan 2} buah AP, dimana pada skenario ini dibuat 2 buah jaringan yang berdekatan dengan channel yang sama pada masing-masig jaringan. Jaringan 1 dan jaringan 2 sama-sama menggunakan channel 1. Masing-masing jaringan tersebut terdiri dari 2 buah laptop dan 1 buah AP, dimana laptop 1 bertindak sebagai server yang terhubung dengan AP menggunakan kabel UTP, dan laptop kedua sebagai client yang terhubung dengan AP menggunakan wireless. Pada ke dua jaringan tersebut masing-masing AP dikonfigurasi menggunakan channel yang sama. Dimana jaringan 2 digunakan sebagai interfreter (penginterferensi) pada jaringan 1. Mekenisme yang dilakukan dapat dilihat pada Gambar 4.

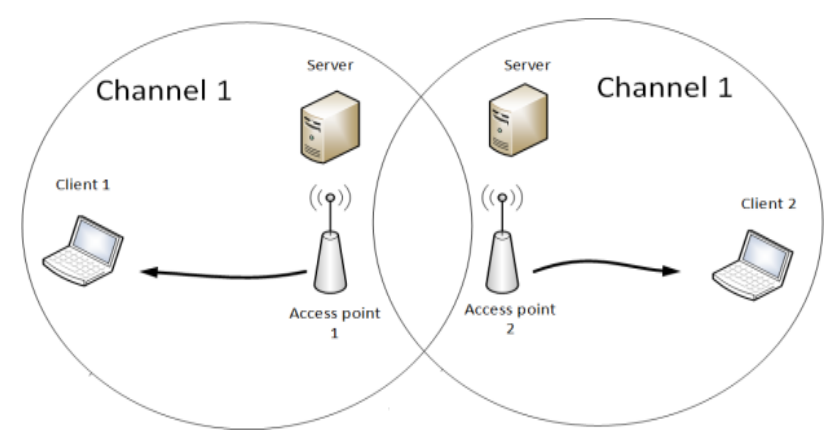

Gambar 4. Pengukran pada lingkungan dengan interferensi menggunakan dua channel yang sama

\subsubsection{Pengukuran pada lingkungan dengan interferensi menggunakan tiga channel yang sama.}

Pada skenario ini digunakan 6 buah laptop dan 3 buah AP, dimana pada skenario ini dibuat 3 buah jaringan yang berdekatan dengan channel yang sama pada masing-masing jaringan. Jaringan 1 , jaringan 2 dan jaringan 3 sama-sama menggunakan channel 1 . Masing-masing jaringan tersebut terdiri dari 2 buah laptop dan 1 buah AP, dimana laptop 1 bertindak sebagai server yang terhubung dengan AP melalui kabel UTP, dan laptop kedua sebagai client yang 
terhubung dengan AP menggunakan wireless. Pada ke tiga jaringan tersebut masing-masing AP dikonfigurasi menggunakan channel yang sama. Dimana jaringan 2 dan jaringan 3 digunakan sebagai interfreter (penginterferensi) pada jaringan 1. Mekenisme pengukuran yang dilakukan dapat dilihat pada Gambar 5.

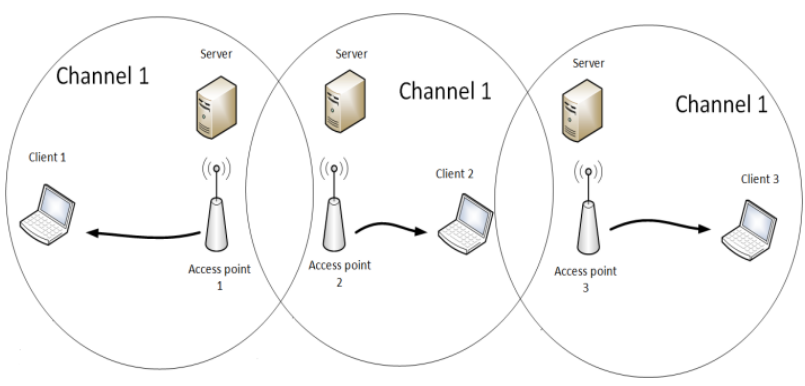

Gambar 5. Pengukuran pada lingkungan dengan interferensi menggunakan tiga channel yang sama.

\subsubsection{Pengukuran pada lingkungan dengan interferensi menggunakan kanal interferensi yang berbeda dan berdekatan.}

Pada skenario pengukuran pada lingkungan dengan interferensi menggunaan kanal yang berbeda dan berdekatan ini dilakukan 3 buah percobaan.

\subsubsection{Pengukuran pada lingkungan dengan interferensi menggunakan channel 1 dan channel 2 yang berdekatan}

Pada skenario ini digunakan 4 buah laptop dan 2 buah AP, dimana pada skenario ini dibuat 2 buah jaringan yang berdekatan dengan channel yang berbeda pada masing-masig jaringan. Masing-masing jaringan tersebut terdiri dari 2 buah laptop dan 1 buah AP, dimana laptop 1 bertindak sebagai server yang terhubung dengan AP menggunakan kabel UTP, dan laptop kedua sebagai client yang terhubung dengan AP melalui media wireless. Pada ke dua jaringan tersebut masing-masing AP dikonfigurasi menggunakan channel yang berbeda, jaringan 1 menggunakan channel 1, jaringan 2 menggunakan channel 2. Jaringan 2digunakan sebagai interfreter (penginterferensi) pada jaringan 1. Mekenisme pengukuran yang dilakukan dapat dilihat pada Gambar 6.

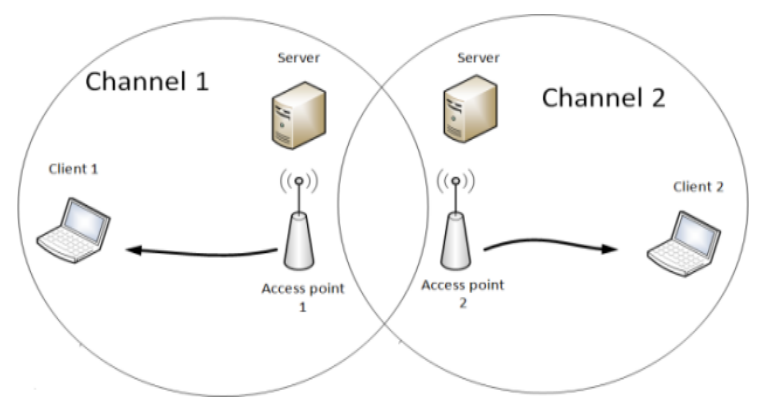

Gambar 6. skenario pengukuran pada lingkungan dengan channel 1 dan channel 2 yang berdekatan.

4.1.4.2 Pengukuran pada lingkungan dengan interferensi menggunakan channel 1 dan channel 3 yang berdekatan

Pada skenario ini peralatan dan mekanisme pengukuran yang dilakukan sama seperti scenario sebelumnya.

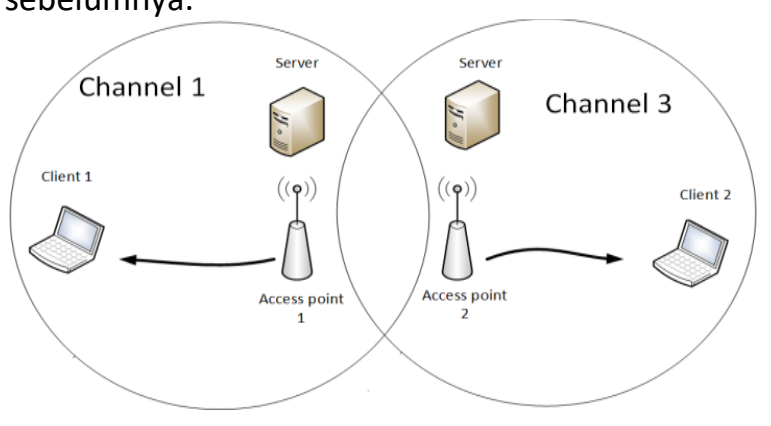

Gambar 7. skenario pengukuran pada lingkungan dengan channel 1 dan channel 3 yang berdekatan.

\subsubsection{Pengukuran pada lingkungan dengan interferensi menggunakan channel 1 dan channel 4 yang berdekatan}

Pada skenario ini peralatan dan mekanisme pengukuran yang dilakukan sama seperti skenario sebelumnya.

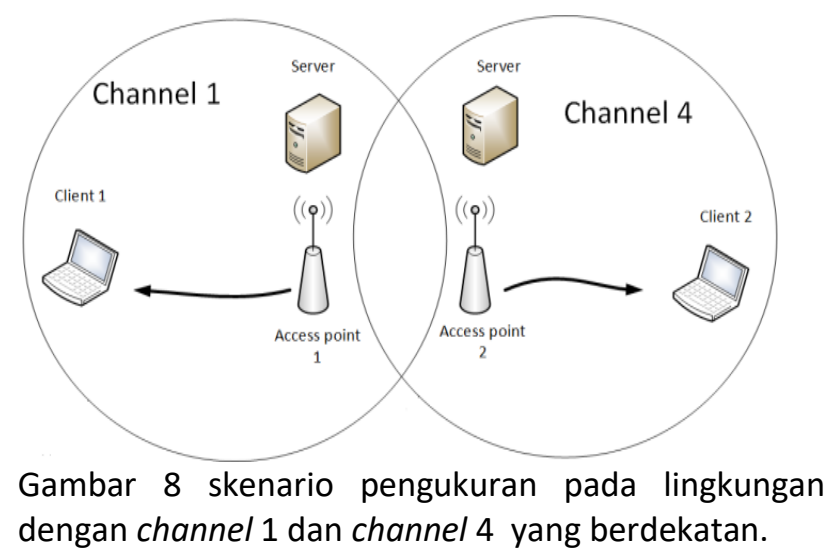




\subsubsection{Parameter-Parameter Pengujian}

Parameter yang akan diuji atau diukur dalam penelitian ini adalah bandwidth, jitter, dan packet loss. Pengukuran parameter ini menggunakan software insider dan Jperf.

\section{HASIL DAN PeMBaHASAN}

\subsection{Hasil dan Analisis Pengukuran}

Hasil pengukuran yang diperoleh dengan menggunakan jperf meliputi bandwidth, jitter dan packet loss. Besar data yang dibangkitkan yakni sebesar 18,75 MB atau setara dengan 150 Mbps yang merupakan kecepatan maksimal yang ditawarkan perangkat.

\subsubsection{Pengukuran parameter bandwidth pada kondisi jaringan tanpa interferensi}

Pada skenario ini digunakan dua buah laptop dan satu buah access point, laptop pertama berperan sebagai server yang terhubung menggunakan kabel UTP dan laptop ke dua sebagai client yang terhubung menggunakan wireless. Penempatan posisi access point, dan laptop konstan dengan jarak 5 meter. Data hasil pengukuran parameter bandwidth pada kondisi jaringan tanpa interferensi dapat dilihat pada pada Tabel I.

Tabel I Pengukuran Parameter BandWidth Pada KondisI JARINGAN TANPA INTERFERENSI.

\begin{tabular}{|c|c|c|}
\hline Kondisi & $\begin{array}{c}\text { Pengujian } \\
\text { ke- }\end{array}$ & $\begin{array}{c}\text { Rata-rata } \\
\text { Bandwidth } \\
\text { (Kbps) }\end{array}$ \\
\hline \multirow{3}{*}{$\begin{array}{c}\text { Tanpa } \\
\text { interferensi }\end{array}$} & 1 & 18419.6 \\
\cline { 2 - 3 } & 2 & 18503.3 \\
\cline { 2 - 3 } & 3 & 18287.1 \\
\cline { 2 - 3 } & 5 & 17953.4 \\
\hline \multicolumn{2}{|c|}{ Rata-rata } & 18568.8 \\
\hline \multicolumn{2}{|c|}{} & 18346.44 \\
\hline
\end{tabular}

Dari Tabel II dapat dilihat bahwa besar nilai ratarata bandwidth yang didapatkan pada lima kali percobaan pada kondisi jaringan tanpa interferensi sebesar $18346.44 \mathrm{Kbps}$. Berdasarkan data bandwidth tersebut, berarti bahwa bandwidth yang didapatkan sangat besar sehingga kondisi jaringan berada pada kondisi maksimal .

\subsubsection{Pengukuran Parameter Jitter pada Kondisi Jaringan tanpa Interferensi}

Dari Tabel II dapat dilihat bahwa besar nilai ratarata jitter yang didapatkan pada lima kali percobaan pada kondisi jaringan tanpa interferensi sebesar 0.576825 ms. Berdasarkan data jitter tersebut, menunjukkan bahwa kualitas jaringan dalam keadaan sangat baik.

TABEL II PENGUKURAN PARAMETER JITTER PADA KONDISI JARINGAN TANPA INTERFERENSI.

\begin{tabular}{|c|c|c|}
\hline Kondisi & $\begin{array}{c}\text { Pengujian } \\
\text { ke- }\end{array}$ & $\begin{array}{c}\text { Rata-rata } \text { jitter } \\
(\mathrm{ms})\end{array}$ \\
\hline \multirow{4}{*}{ Tanpa interferensi } & 1 & 0.5597 \\
\cline { 2 - 3 } & 2 & 0.6843 \\
\cline { 2 - 3 } & 3 & 0.4121 \\
\cline { 2 - 3 } & 4 & 0.6512 \\
\cline { 2 - 3 } & 5 & 0.4591 \\
\hline \multicolumn{2}{|c|}{ Rata-rata } & 0.576825 \\
\hline
\end{tabular}

\subsubsection{Pengukuran parameter packet loss pada kondisi jaringan tanpa interferensi}

Dari Tabel III dapat dilihat bahwa besar nilai ratarata packet loss yang didapatkan pada lima kali percobaan pada kondisi jaringan tanpa interferensi sebesar $0.30 \%$. Berdasarkan data packet loss tersebut, menunjukkan bahwa kualitas jaringan dalam keadaan sangat baik.

TABel III PengukURAn PARAMETER PACKet Loss PAdA KONDISI JARINGAN TANPA INTERFERENSI.

\begin{tabular}{|c|c|c|}
\hline Kondisi & $\begin{array}{c}\text { Pengujian } \\
\text { ke- }\end{array}$ & $\begin{array}{c}\text { Rata-rata packrt } \\
\text { loss } \\
(\%)\end{array}$ \\
\hline \multirow{3}{*}{ Tanpa interferensi } & 1 & $0.44 \%$ \\
\cline { 2 - 3 } & 2 & $0.24 \%$ \\
\cline { 2 - 3 } & 3 & $0.34 \%$ \\
\cline { 2 - 3 } & 4 & $0.18 \%$ \\
\cline { 2 - 3 } & 5 & $0.30 \%$ \\
\hline \multicolumn{2}{|c|}{ Rata-rata } & $0.30 \%$ \\
\hline \multicolumn{2}{|c|}{} & \\
\hline
\end{tabular}

\subsubsection{Hasil pengukuran dan analisis pada kondisi jaringan dengan interferensi bluetooth (skenario 2)}

Pengukuran dilakukan dengan membangkitkan data sebesar 18,75 MB yang dikirimkan dari client menuju server dengan adanya komunikasi Bluetooth disekitarnya, dimana jarak Bluetooth $1 \mathrm{~m}$ antara server dan client. Hasil pengukuran yang diperoleh dengan menggunakan Jperf meliputi bandwidth, jitter dan packet loss.

\subsubsection{Pengukuran parameter bandwidth pada kondisi jaringan dengan interferensi bluetooth.}

Pada skenario ini digunakan dua buah laptop dan satu buah access point, laptop pertama berperan sebagai server yang terhubung menggunakan kabel UTP dan laptop ke dua sebagai client yang terhubung 
menggunakan wireless, dan sebuah perangkat yang memiliki fitur Bluetooth. Penempatan posisi access point, dan laptop konstan dengan jarak 5 meter dan penempatan fitur Bluetooth ditempatkan diantara laptop server dan client. Hasil pengukuran pada kondisi dengan interferensi Bluetooth, didapatkan parameter bandwidth seperti pada Tabel IV.

TABEL IV PENGUKURAN BANDWIDTH PADA KONDISI JARINGAN DENGAN INTERFERENSI BLUETOOTH.

\begin{tabular}{|c|c|c|}
\hline Kondisi & $\begin{array}{c}\text { Pengujian } \\
\text { ke- }\end{array}$ & $\begin{array}{c}\text { Rata-rata bandwidth } \\
\text { (Kbps) }\end{array}$ \\
\hline \multirow{4}{*}{$\begin{array}{c}\text { Jaringan dengan } \\
\text { Interferensi } \\
\text { Bluetooth }\end{array}$} & 1 & 7633.3 \\
\cline { 2 - 3 } & 2 & 7751.4 \\
\cline { 2 - 3 } & 3 & 7406.1 \\
\cline { 2 - 3 } & 5 & 7739.7 \\
\hline \multicolumn{2}{|c|}{ Rata-rata } & 7293.5 \\
\hline
\end{tabular}

Dari Tabel IV dapat dilihat bahwa nilai rata-rata bandwidth dari lima kali pengujian pada kondisi jaringan dengan interferensi Bluetooth sebesar 7564.8 Kbps. Berdasarkan data bandwidth tersebut, terjadi penurunan setengah dari besar bandwidth yang dibangkitkan.

\subsubsection{Pengukuran parameter jitter pada kondisi jaringan dengan interferensi bluetooth}

TABEL V PENGUKURAN JITTER PADA KONDISI JARINGAN DENGAN INTERFERENSI BLUETOOTH.

\begin{tabular}{|c|c|c|}
\hline Kondisi & $\begin{array}{c}\text { Pengujian } \\
\text { ke- }\end{array}$ & $\begin{array}{c}\text { Rata-rata jitter } \\
(\mathrm{ms})\end{array}$ \\
\hline \multirow{4}{*}{$\begin{array}{c}\text { Jaringan dengan } \\
\text { Interferensi Bluetooth }\end{array}$} & 1 & 8.4028 \\
\cline { 2 - 3 } & 2 & 11.2374 \\
\cline { 2 - 3 } & 3 & 7.4052 \\
\cline { 2 - 3 } & 4 & 7.3417 \\
\hline \multicolumn{2}{|c|}{ Rata-rata } & 10.2121 \\
\hline
\end{tabular}

Dari Tabel $\mathrm{V}$ dapat dilihat bahwa nilai rata-rata jitter dari lima kali pengujian pada kondisi jaringan dengan interferensi Bluetooth nilai rata-rata jitter sebesar 8.91984 ms. Berdasarkan data jitter tersebut, berarti kualitas jaringan dalam keadaan baik.

\subsubsection{Pengukuran Parameter packet loss pada Kondisi Jaringan dengan Interferensi Bluetooth.}

Dari Tabel VI dapat dilihat bahwa nilai rata-rata packet loss dari lima kali pengujian pada kondisi jaringan dengan interferensi Bluetooth nilai rata-rata jitter sebesar $8.67 \%$. Berdasarkan data packet loss tersebut, berarti kualitas jaringan dalam keadaan baik.

Tabel VI Pengukuran packet loss pada kondisi jaringan dengan interferensi Bluetooth.

\begin{tabular}{|c|c|c|}
\hline Kondisi & $\begin{array}{c}\text { Pengujian } \\
\text { ke- }\end{array}$ & $\begin{array}{c}\text { Rata-rata packet loss } \\
(\%)\end{array}$ \\
\hline \multirow{3}{*}{$\begin{array}{c}\text { Jaringan dengan } \\
\text { Interferensi Bluetooth }\end{array}$} & 1 & $7.00 \%$ \\
\cline { 2 - 3 } & 2 & $7.25 \%$ \\
\cline { 2 - 3 } & 3 & $7.00 \%$ \\
\cline { 2 - 3 } & 5 & $10.00 \%$ \\
\hline Rata-rata & $11.8 \%$ \\
\hline
\end{tabular}

4.1.5 Perbandingan quality of service pada kondisi jaringan dengan interferensi 2 channel sama dan 3 channel sama yang berdekatan berdasarkan parameter pengukuran

Pada kondisi jaringan tanpa interferensi digunakan dua buah laptop dan satu buah access point, laptop pertama berperan sebagai server yang terhubung menggunakan kabel UTP dan laptop ke dua sebagai client yang terhubung menggunakan wireless. Pada skenario dengan kondisi jaringan interferensi 2 channel sama digunakan empat buah laptop dan dua buah access point, dan dibuat dua buah jaringan berbeda dimana masing-masing jaringan sama-sama menggunakan channel 1. Laptop pertama berperan sebagai server yang terhubung menggunakan kabel UTP dan laptop ke dua sebagai client yang terhubung menggunakan wireless. Pada skenario dengan kondisi jaringan interferensi 3 channel sama digunakan enam buah laptop dan tiga buah access point, dan dibuat tiga buah jaringan berbeda dimana masing-masing jaringan sama-sama menggunakan channel 1. Laptop pertama berperan sebagai server yang terhubung menggunakan kabel UTP dan laptop ke dua sebagai client yang terhubung menggunakan wireless. Penempatan posisi access point dan laptop konstan yaitu dengan jarak 5 meter. kemudian intalasi software Inssider pada salah satu server yang digunakan dalam pengujian dan Instalasi software Jperf pada masing-masing laptop yang digunakan dalam pengukuran. Mengaktifkan Inssider pada salah satu server untuk mengetahui channel pada jaringan disekitarnya dan mengaktifkan Jperf kemudian melakukan transfer data antara server dan client. Berikut data hasil pengukuran parameter bandwidth 


\subsubsection{Parameter bandwidth}

BANDWIDTH PADA KONDISI TANPA INTERFERENSI 2 CHHANNEL SAMA \& 3 CHANNEL SAMA

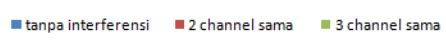

18346.44

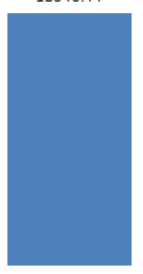

1982.15

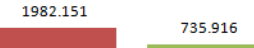

Gambar 9 Diagram pengaruh interferensi terhadap nilai bandwidth pada jaringan tanpa interferensi, interferensi 2 channel sama dan interferensi 3 channel sama.

Dari Gambar 9 dapat dilihat bahwa total rata-rata bandwidth pada kondisi jaringan tanpa interferensi sebesar $18346.44 \mathrm{Kbps}$, total bandwidth pada kondisi jaringan dengan interferensi 2 channel sama sebesar 1982.151 Kbps dan pada kondisi jaringan dengan interferensi 3 channel sama sebesar $735.916 \mathrm{Kbps}$, dengan demikian dapat diketahui bahwa semakin banyak jumlah access point yang menggunakan channel sama dan berdekatan pada suatu daerah cakupan akan menyebabkan menurunnya nilai bandwidth yang diterima.

\subsubsection{Parameter jitter}

\section{JITTER PADA KONDISI TANPA INTERFERENSI, 2} CHANNEL SAMA \& 3 CHANNEL SAMA

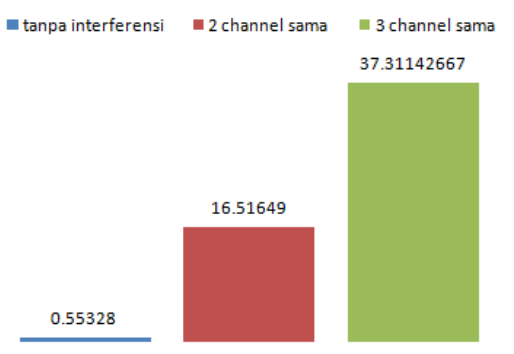

Gambar 10. Diagram pengaruh interferensi terhadap nilai jitter pada jaringan tanpa interferensi, interferensi 2 channel sama dan interferensi 3 channel sama

Dari Gambar 10 dapat dilihat bahwa total ratarata jitter pada kondisi jaringan tanpa interferensi sebesar $0.55328 \mathrm{~ms}$, total bandwidth pada kondisi jaringan dengan interferensi 2 channel sama sebesar $16.51649 \mathrm{~ms}$ dan pada kondisi jaringan dengan interferensi 3 channel sama sebesar $37.31143 \mathrm{~ms}$, dengan demikian dapat diketahui bahwa semakin banyak jumlah access point yang menggunakan channel yang sama dan berdekatan pada suatu daerah cakupan maka semakin besar juga jitter yang diterima jaringan sehingga kondisi jaringan mennjadi kurang stabil.

\subsubsection{Parameter packet loss}

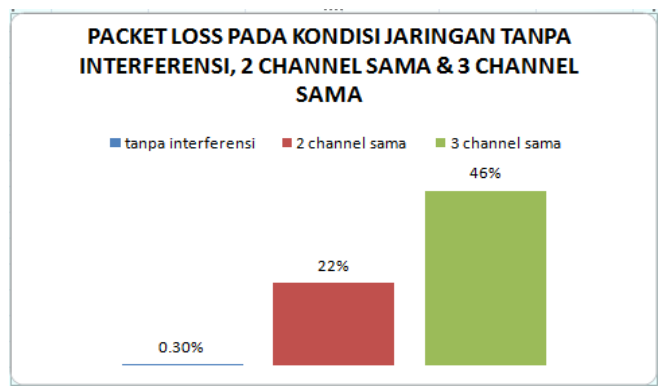

Gambar 11. Diagram pengaruh interferensi terhedap nilai packet loss pada jaringan tanpa interferensi, interferensi 2 channel sama dan interferensi 3 channel sama.

Dari Gambar 11 dapat dilihat bahwa total ratarata packet loss pada kondisi jaringan tanpa interferensi sebesar $0.30 \%$, total bandwidth pada kondisi jaringan dengan interferensi 2 channel sama sebesar $22 \%$ dan pada kondisi jaringan dengan interferensi 3 channel sama sebesar $46 \%$, dengan demikian dapat diketahui bahwa semakin banyak jumlah access point yang menggunakan channel yang sama dan berdekatan pada suatu daerah cakupan maka semakin besar juga packet lossnya sehingga kondisi jaringan menjadi kurang stabil.

\subsubsection{Perbandingan quality of service pada kondisi jaringan tanpa interferensi, interferensi bluetooth, dan interferensi pada channel berbeda}

Pada kondisi jaringan tanpa interferensi digunakan dua buah laptop dan satu buah access point, laptop pertama berperan sebagai server yang terhubung menggunakan kabel UTP dan laptop ke dua sebagai client yang terhubung menggunakan wireless.

Pada skenario dengan kondisi jaringan dengan interferensi channel 1 dan 2 digunakan empat buah laptop dan dua buah access point, dan dibuat dua buah jaringan berbeda dimana masing-masing jaringan menggunakan channel 1 dan channel 2 . Laptop pertama berperan sebagai server yang terhubung menggunakan kabel UTP dan laptop ke dua sebagai client yang terhubung menggunakan wireless. Pada skenario dengan kondisi jaringan 
dengan interferensi channel 1 dan 3 digunakan empat buah laptop dan dua buah access point, dan dibuat dua buah jaringan berbeda dimana masingmasing jaringan menggunakan channel 1 dan channel 3. Laptop pertama berperan sebagai server yang terhubung menggunakan kabel UTP dan laptop ke dua sebagai client yang terhubung menggunakan wireless. skenario dengan kondisi jaringan dengan interferensi channel 1 dan 4 digunakan empat buah laptop dan dua buah access point, dan dibuat dua buah jaringan berbeda dimana masing-masing jaringan menggunakan channel 1 dan channel 4 . Laptop pertama berperan sebagai server yang terhubung menggunakan kabel UTP dan laptop ke dua sebagai client yang terhubung menggunakan wireless. Penempatan posisi access point dan laptop konstan yaitu dengan jarak 5 meter. Kemudian intalasi software Inssider pada salah satu server yang digunakan dalam pengujian dan Instalasi software Jperf pada masing-masing laptop yang digunakan dalam pengukuran. Mengaktifkan Inssider pada salah satu server untuk mengetahui channel pada jaringan disekitarnya dan mengaktifkan Jperf kemudian melakukan transfer data antara server dan client. Berikut data hasil pengukurannya.

\subsubsection{Parameter bandwidth}

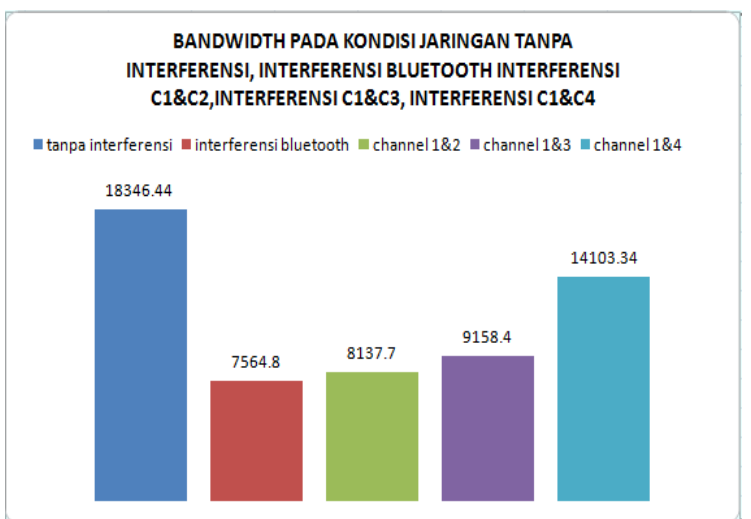

Gambar 12. Diagram pengaruh interferensi

berdasarkan nilai bandwidth

Dari Gambar 12 dapat dilihat bahwa total ratarata bandwidth pada kondisi jaringan tanpa interferensi sebesar $18346.44 \mathrm{Kbps}$, total bandwidth pada kondisi jaringan dengan interferensi Bluetooth sebesar $7564.8 \mathrm{Kbps}$, kondisi jaringan dengan interferensi channel 1 dan 2 sebesar 8137.7 Kbps, pada kondisi jaringan dengan interferensi channel 1 dan 3 sebesar 9158.4 Kbps, dan pada kondisi jaringan dengan interferensi channel 1 dan 4 sebesar 14103.34 Kbps.
Dengan demikian dapat diketahui bahwa access point yang bekerja pada jaringan yang bebas interferensi akan mendapatkan bandwidth maksimal sehingga kinerja jaringan stabil, sedangkan access point yang menggunakan pita frekuensi yang sama dengan perangkat disekitarnya dalam hal ini Bluetooth akan mengalami penurunan bandwidth setengah dari bandwidth yang diterima jaringan tanpa interferensi. Semakin dekat jarak access point yang menggunakan channel berbeda dan berdekatan pada satu daerah cakupan akan mengalami penurunan bandwidth . Dan sebaliknya semakin jauh jarak access point yang menggunakan channel berbeda dan berdekatan pada suatu daerah cakupan maka semakin besar nilai bandwidth yang diterima.

\subsubsection{Parameter Jitter}

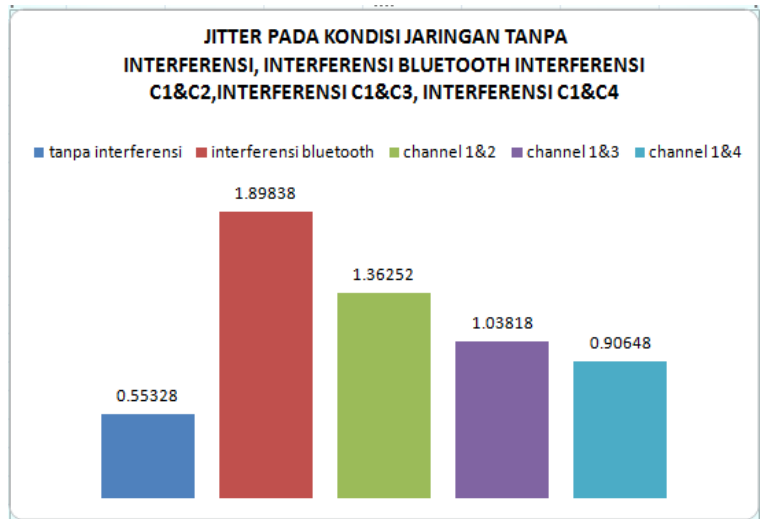

Gambar 13. Diagram pengaruh interferensi berdasarkan nilai jitter

Dari Gambar 13 dapat dilihat bahwa total ratarata jitter pada kondisi jaringan tanpa interferensi sebesar $0.55328 \mathrm{~ms}$, total jitter pada kondisi jaringan dengan interferensi Bluetooth sebesar 1.89838 Kbps, kondisi jaringan dengan interferensi channel 1 dan 2 sebesar $1.36252 \mathrm{~ms}$, pada kondisi jaringan dengan interferensi channel 1 dan 3 sebesar $1.03818 \mathrm{~ms}$, dan pada kondisi jaringan dengan interferensi channel 1 dan 4 sebesar $0.90648 \mathrm{~ms}$.

Dengan demikian dapat diketahui bahwa access point yang bekerja pada jaringan yang bebas interferensi mendapatkan jitter terkecil sehingga proses transmisi sinyal lebih cepat. Sedangkan access point yang menggunakan pita frekuensi yang sama dengan perangkat disekitarnya dalam hal ini Bluetooth mengalami kenaikan jitter paling tinggi. Semakin dekat jarak access point yang menggunakan channel berbeda dan berdekatan pada satu daerah cakupan mengalami peningkatan nilai jitter. Dan sebaliknya semakin jauh jarak access point yang 
menggunakan channel berbeda dan berdekatan pada suatu daerah cakupan maka semakin kecil nilai jitter yang diterima.

\subsubsection{Parameter packet loss}

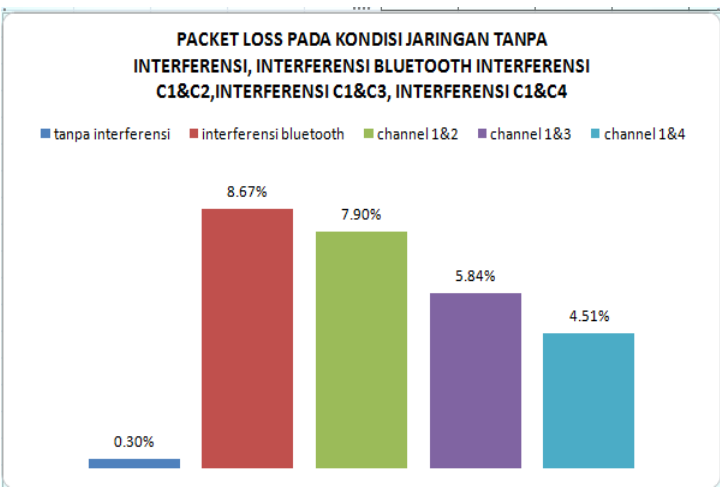

Gambar 14. Diagram pengaruh interferensi berdasarkan nilai packet loss

Dari Gambar 14. dapat dilihat bahwa total ratarata jitter pada kondisi jaringan tanpa interferensi sebesar $0.30 \%$, total jitter pada kondisi jaringan dengan interferensi Bluetooth sebesar $8.67 \%$, kondisi jaringan dengan interferensi channel 1 dan 2 sebesar $7.90 \%$, pada kondisi jaringan dengan interferensi channel 1 dan 3 sebesar $5.84 \%$, dan pada kondisi jaringan dengan interferensi channel 1 dan 4 sebesar $4.51 \%$.

Dengan demikian dapat diketahui bahwa access point yang bekerja pada jaringan yang bebas interferensi memiliki packet loss yang kecil. Dan access point yang menggunakan pita frekuensi yang sama dengan perangkat disekitarnya dalam hal ini Bluetooth juga memiliki packet loss yang kecil. Semakin dekat jarak access point yang menggunakan channel berbeda dan berdekatan pada satu daerah cakupan mengalami peningkatan nilai packet loss. Dan sebaliknya semakin jauh jarak access point yang menggunakan channel berbeda dan berdekatan pada suatu daerah cakupan maka semakin kecil nilai packet lossnya.

\section{Kesimpulan dan SARAN}

\subsection{Kesimpulan}

1. Access point yang bekerja pada jaringan yang bebas interferensi akan mendapatkan bandwidth maksimal, nilai jitter dan packet loss yang kecil sehingga kinerja jaringan stabil. Pada interferensi 2 channel sama terjadi penurunan nilai bandwidth sebesar $89 \%$, peningkatan nilai jitter sebesar $97 \%$ dan peningkatan nilai packet loss sebesar 21.7\%, interferensi 3 channel sama mengalami penurunan bandwidth sebesar $96 \%$, peningkatan nilai jitter sebesar 99\%, dan peningkatan nilai packet loss sebesar $45.7 \%$.

2. Access point dengan perangkat Bluetooth disekitarnya mengalami penurunan bandwidth sebesar 59\%, kenaikan nilai jitter sebesar $71 \%$, dan penurunan nilai packet loss sebesar $8.34 \%$. Pada interferensi channel 1 dan 2 mengalami penurunan bandwidth sebesar $56 \%$, kenaikan nilai jitter sebesar $59 \%$, dan kenaikan packet loss sebesar 7.6\%, interferensi channel 1 dan 3 mengalami penurunan bandwidth sebesar $50 \%$, kenaikan jitter sebesar $47 \%$, dan kenaikan nilai packet loss sebesar 5.54\%. Dan untuk interferensi channel 1 dan 4 mengalami penurunan bandwidth sebesar $23 \%$, kenaikan jitter sebesar $39 \%$,dan kenaikan nilai packet loss sebesar $4.21 \%$.

3. Dari hasil pengukuran dan analisis menunjukkan bahwa kualitas jaringan dipengaruhi karena adanya interferensi. Dimana jika jaringan bebas dari interferensi di sekitarnya maka kualitas jaringan akan semakin baik, jika jaringan mengalami interferensi karena menggunakan pita frekuensi yang sama pada suatu daerah cakupan yang sama dapat mempengaruhi kualitas jaringan meskipun tidak terlalu signifikan, jika semakin banyak jumlah channel sama yang menginterferensi suatu jaringan maka kualitas jaringan semakin buruk, dan semakin dekat jarak channel berbeda pada suatu jaringan juga mempengaruhi adanya interferensi pada jaringan disekitarnya.

\subsection{Saran}

Pada penelitian ini tidak menggunakan lebih dari satu access point dengan channel yang sama. Pilih channel terjauh untuk menghindari adanya interferensi. Parameter yang diukur pada penelitian ini yaitu bandwidth, jitter dan packet loss dengan menggunakan standar jaringan IEEE 802.11n. Dan untuk penelitian selanjutnya disarankan untuk melakukan pengukuran dengan parameter lainnya seperti throughput dan delay, dan menggunakan standar jaringan terbaru ataupun media transmisi lainnya.

\section{DAFTAR PUSTAKa}

[1] I.W.A. Arimbawa, "Wireless mesh network berbasis IEEE $802.11 \mathrm{~b} / \mathrm{g}$ sebagai solusi nirkabel jaringan komunikasi sebuah komplek perumahan", Universitas Gajah Mada Yogyakarta, 2011. 
[2] I.W.J.A. Prasetya, "Analisis parameter QoS terhadap pengaruh pertambahan jarak dan interferensi WI-FI melalui jaringan Bluetooth", Fakultas Teknik Universitas Jember, 2015.

[3] I. Jun, "Analisis deteksi interferensi dan penurunan performance hotspot universitas bina darma disekitar area jarinagan", Universitas Bina Darma, 2010.

[4] A. Insani, "Pengaruh interferensi performansi akibat interferensi sistem bluetooth dan WLAN 802.11b", Pusat Penelitian Kalibrasi Instrumentasi Metrologi, 2011.

[5] K. Riklan, "Analisis interferensi bluetooth terhadap wireless LAN IEEE 802.11b pada frekuensi 2,4 GHz", Fakultas Teknik Elektro Universitas Telkom, 2012.

[6] Nurmalia, "Pengukuran interferensi (AP) untuk mengetahui Quality Of Service (QOS)", Fakultas Sains dan Teknologi Universitas Islam Negri, 2010.
[7] Rosiwan, "Pengukuran dan analisa pengaruh interferensi terhadap Qos pada standar jaringan IEEE 802.11b", Fakultas Teknik Universitas Mataram, 2011.

[8] V. Agus, "Analisa pengaruh besar area hotspot dan interferensi pada WLAN IEEE 802.11b, Departemen Teknik Elektro Institut Teknologi Telkom, 2009.

[9] M. R. Arief, "Teknologi jaringan tanpa kabel (wireless)", Seminar Nasional Teknologi, hal. 1-8, 2007.

[10] I. Hafazah, "Analisis pengaruh jumlah client dan jarak cakupan wireless AP IEEE $802.11 \mathrm{n}$ terhadap kualitas jaringan WLAN menggunakan teknik UR dan WDS", Fakultas Teknik Universitas Mataram, 2016. 